\title{
Effect of carboxymethylcellulose sodium addition as stabilizer for physicochemical characteristic of purple sweet potato fortified yogurt (Ipomoea batatas $\mathbf{L}$.)
}

\author{
Uci Ary Lantika ${ }^{1}$, Fitrianti Darusman ${ }^{2}$, Widad Aghnia Shalannandia ${ }^{3}$, \\ Astrid Feinisa Khairani* ${ }^{* 3,4}$ \\ ${ }^{1}$ Medical Biology Departement, Faculty of Medicine, Universitas Islam Bandung \\ Jl. Tamansari No.1 Bandung 40116, West Java, Indonesia \\ ${ }^{2}$ Pharmacy Department, FMIPA, Universitas Islam Bandung \\ Jl. Tamansari No.1 Bandung 40116, West Java, Indonesia \\ ${ }^{3}$ Research Centre of Oncology and Stem Cell, Faculty of Medicine, Universitas Padjadjaran, \\ Jl Eijkman No. 38, Bandung 40161, West Java, Indonesia \\ ${ }^{4}$ Division of Cell Biology, Department of Biomedical Sciences, Faculty of Medicine, Universitas Padjadjaran \\ Jl. Raya Bandung - Sumedang Km 21.6, Jatinangor, Sumedang, West Java, Indonesia
}

Submitted: 28 September $2020 \quad$ Reviewed: 05-01-2021 Accepted: 23-03-2021

\begin{abstract}
The yoghurt consisted of low-fat milk, three bacterial strains starter, which included: $L$. bulgaricus ATCC 11842, L. plantarum ATCC 8014, and B. longum (1:1:1); purple sweet potato puree (Ipomoea batatas, L.) and carboxymethylcellulose sodium with the concentration of $0.6 \%$, $1.2 \%$, and $1.8 \%$. Purple sweet potato fortification in yogurt can prevent hypercholesterolemic conditions because it inhibits lipid and sugar absorption in the intestine. Unfortunately, there is one shortcoming in the production of yogurt which affects the final product quality. This shortcoming is in the decrease in the air holding capacity (whey off) during the production due to the $\mathrm{pH}$ level within the isoelectric point of casein. This causes precipitation and phase separation. This study will add a stabilizer to the formula to overcome it. The stabilizer used is carboxymethylcellulose sodium, which is semi-synthetic water-soluble ester polymer cellulose. This study aimed to determine the optimal concentration of carboxymethylcellulose sodium and its effect on purple sweet potato yogurt's physicochemical and organoleptic properties. The product quality evaluations were on organoleptic evaluation, density, viscosity, and $\mathrm{pH}$ level. Centrifugation and freeze-thaw tests were also performed to evaluate product stability. The results showed that carboxymethylcellulose sodium could maintain the stability of purple sweet potato yogurt by binding the air content, increasing consistency, and smoothing the texture even though it did not affect the freezing point of the product. This study gave the best results for purple sweet potato yogurt with $1.2 \%$ carboxymethylcellulose sodium concentration.
\end{abstract}

Keywords: carboxymethylcellulose sodium, stabilizer, yogurt, fortification, purple sweet potato

*Corresponding author:

Astrid Feinisa Khairani

Division of Cell Biology, Department of Biomedical Sciences, Faculty of Medicine, Universitas Padjadjaran

J1. Raya Bandung - Sumedang Km 21.6, Jatinangor, Sumedang, West Java, Indonesia

Email: astrid.khairani@unpad.ac.id 


\section{INTRODUCTION}

It is common to add fruit to the raw material for yogurt production as a modification (Teshome et al., 2017). Its purpose is to improve the taste and product nutritions, such as antioxidants (Nguyen and Hwang, 2016; Perna et al., 2014). Tubers like purple sweet potato contain antioxidants (Yang et al., 2019). This study used purple sweet potato to fortify yogurt. Fortification is the process of purposely adding one or more certain nutrients to a food product to prevent nutrient deficiencies or adding specific nutrients (Raikos et al., 2018; Teshome et al., 2017).

Purple sweet potato has the Latin name Ipomoea batatas L. It has skin and flesh deep purple color. Anthocyanin pigments, as antioxidant compounds, are also found in purple sweet potatoes (He et al., 2015; Tokusoglu and Yildirim, 2012). It is worth in preventing premature aging, cancer, and degenerative diseases ( $\mathrm{Ju}$ et al., 2011; Tsuda, 2016). Anthocyanins have antimutagenic and anticarcinogenic potentials, as we have reported in the previous study. This compound can also prevent liver disease, reduce blood sugar levels, and as an antihypertensive (Zhao et al., 2013). Purple sweet potato fortified yogurt takes part in lipid and sugar absorption in the intestine to prevent hypercholesterolemia. (Khairani et al., 2020).

In the previous study, phase separation occurred during yogurt production fortified with purple sweet potato. The $\mathrm{pH}$ level of yogurt tends to drop in the isoelectric range of casein during production because the purple sweet potato's hydrophobic means it has high polysaccharides. As the impact, water retention decreased, which affects product quality like precipitation and separation. (Sudajana et al., 2013).

To solve this problem, we took carboxymethylcellulose sodium. Carboxymethylcellulose sodium is a semi-synthetic water-soluble ester polymer cellulose. It is a water-soluble semisynthetic cellulose ester polymer. So, this can be an option as a stabilizer in the composition (Cakrawati and Kusumah, 2016). This is to maintain product stability so that solid particles are evenly distributed and avoided from precipitation. It is also a water binder, thickener, emulsion stabilizer and gives a gum texture (Arancibia et al., 2016; Bhattarai and Pradhananga, 2015). However, the optimal concentration of carboxymethylcellulose sodium as a stabilizer for enriched purple sweet potato yogurt is still unknown.

This study aimed to know the optimal concentration of carboxymethylcellulose sodium as a stabilizer and its effects on purple sweet potato (Ipomoea batatas L.) yogurt's physicochemical characteristics.

\section{MATERIALS AND METHOD \\ Materials}

We used three strains of lactic acid bacteria (LAB) to produce purple sweet potato yoghurt, including Lactobacillus bulgaricus ATCC 11842, Lactobacillus plantarum ATCC 8014, and Bifidobacterium longum. Then we took low-fat milk (PT Ultra Jaya), purple sweet potatoes (Ayamurasaki variant) and carboxymethylcellulose sodium (Eagle CMC, No. Batch 19060500102, China).

\section{Methods \\ Purple sweet potato processing}

We used the previous study's method (Khairani et al., 2020) in processing purple sweet potatoes into puree. We washed and steamed 5 grams of purple sweet potato. After that, we took 3 grams to be peeled before cutting it into small pieces and blended it with water (1:1). We filtered the result using a cloth. Then the filtering result, a purplish solution, is used to fortify the yogurt. 


\section{Purple sweet potato yogurt production}

The making process followed the procedure from the previous study (Khairani et al., 2020). All bacterial cultures were revived and cultured on De Man, Rogosa and Sharpe agar (MRS). Then, the inoculation loop was used to inoculate it twice for each strain into $50 \mathrm{~mL}$ of low-fat milk to make the yogurt starter. For about $10 \% \mathrm{v} / \mathrm{v}$ of starter bacteria with a ratio of 1:1:1 for each strain was inoculated into the mixture of low-fat milk and purple sweet potato puree, after added carboxymethylcellulose sodium as described in Table 1 . Then, the yogurt was incubated at $37^{\circ} \mathrm{C}$ for 24 hours.

Table 1. Yoghurt formula

\begin{tabular}{lcccccc}
\hline \multicolumn{1}{c}{ Ingredients } & \multicolumn{3}{c}{$\begin{array}{c}\text { Formula A } \\
(\mathbf{\%} \text { v/v) }\end{array}$} & \multicolumn{3}{c}{$\begin{array}{c}\text { Formula B } \\
(\boldsymbol{\%} \text { v/v })\end{array}$} \\
\cline { 2 - 7 } & $\mathbf{1}$ & $\mathbf{2}$ & $\mathbf{3}$ & $\mathbf{1}$ & $\mathbf{2}$ & $\mathbf{3}$ \\
\hline Combination of 3 strains LAB & 25 & 25 & 25 & 25 & 25 & 25 \\
Carboxymethylcellulose sodium & 0.6 & 1.2 & 1.8 & 0.6 & 1.2 & 1.8 \\
Purple sweet potato puree & 0 & 0 & 0 & 30 & 30 & 30 \\
Low-fat milk & \multicolumn{2}{c}{ Add up to $250 \mathrm{~mL}$} & \multicolumn{3}{c}{ Add up to $250 \mathrm{~mL}$} \\
\hline
\end{tabular}

\section{Physicochemical characteristics}

\section{Organoleptic}

The next process was observing the organoleptic purple sweet potato yogurt, including color, texture, aroma, and taste. And it was conducted before and after incubation.

\section{Density}

The process was continued by using a pycnometer to determine the density. First, an empty pycnometer was weighed using an analytical scale. Then the pycnometer was filled with yogurt and weighed again. Then it was calculated by mentioning Equation 1.

$$
\rho=\frac{m 1-m 2}{V \text { pyeno }}
$$

$$
\begin{array}{ll}
\rho & =\text { Density } \\
\mathrm{m} 1 & =\text { Mass of pycnometer with sample } \\
\mathrm{m} 2 & =\text { Mass of empty pycnometer } \\
\mathrm{V} \text { pycno } & =\text { Volume of pycnometer }
\end{array}
$$

\section{Viscosity}

We used Brookfield viscometer to determine the viscosity and rheology of the sample. Poured $150 \mathrm{ml}$ of the sample into a beaker and lowered the spindle into the sample to the exact limit. Then measured it at the specified speed at 10,20, 50,100, 50, 20, and $10 \mathrm{rpm}$ sequentially. Next, calculated the viscosity value. The data obtained were grouped on shear stress $($ dyne $/ \mathrm{cm} 2)$ and shear rate (rpm) (Izadi et al., 2015).

\section{pH measurement}

The acidic level or $\mathrm{pH}$ level was evaluated using $\mathrm{pH}$ meter (Nirco, Basic 20). The value showed on the screen was recorded, and the $\mathrm{pH}$ was measured three times. 


\section{Centrifugation}

The centrifugation process of the $10 \mathrm{ml}$ yogurt sample was carried out at $3750 \mathrm{rpm}$ for 30 minutes. Then observed the physical characteristics, including organoleptic and phase separation. This treatment is equal to one year of gravity effect towards the sample.

\section{Freeze-thaw}

After storing $50 \mathrm{ml}$ of the yogurt sample in a sedimentation tube which was frozen at $-18^{\circ} \mathrm{C}$ for 24 hours, the yogurt sample was moved to room temperature for 24 hours. The observation was done on physical characteristics, including organoleptic and phase segregation.

\section{RESULT AND DISCUSSION}

The color of purple sweet potato yogurt changed from purple to pink after incubation (Figure 1). This change was expected to happen due to fermentation by lactic acid bacteria during the incubation process, resulted in the degradation of anthocyanin pigment in purple sweet potato (Hornedo-Ortega et al., 2017). The result of the organoleptic and $\mathrm{pH}$ level evaluation before and after incubation was presented in Table 2.

The formula's viscosity with $0.6 \%$ carboxymethylcellulose sodium produced the thinnest result compared to $1.2 \%$ and $1.8 \%$ carboxymethylcellulose sodium. Meanwhile, the yogurt with $1.8 \%$ of carboxymethylcellulose sodium was too thick and was hard to homogenize. Besides, there was foam and precipitation upon incubation, which resulted in discontinuation of observation for this formula. This condition occurs because the viscosity of yogurt product rise aligns with the increase of carboxymethylcellulose sodium concentration (Chairunnissa et al., 2017).

The $\mathrm{pH}$ level of purple sweet potato decreased after incubation (Table 1). This condition happened due to LAB's fermentation process, which produced lactic acid and lowered the product's pH level (Mohan et al., 2020). The $\mathrm{pH}$ level of yogurt formulas in this study were all within the range (pH 4-5) of yogurt manufacture standardization of SNI No. 2981.

A
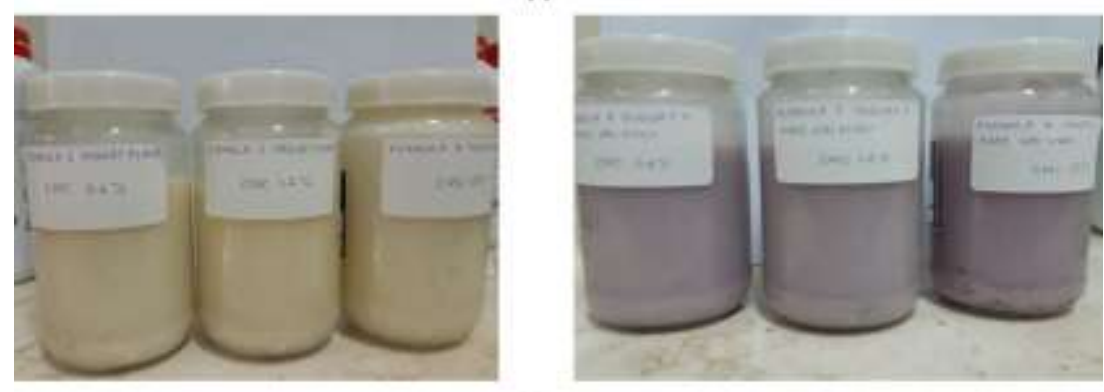

B
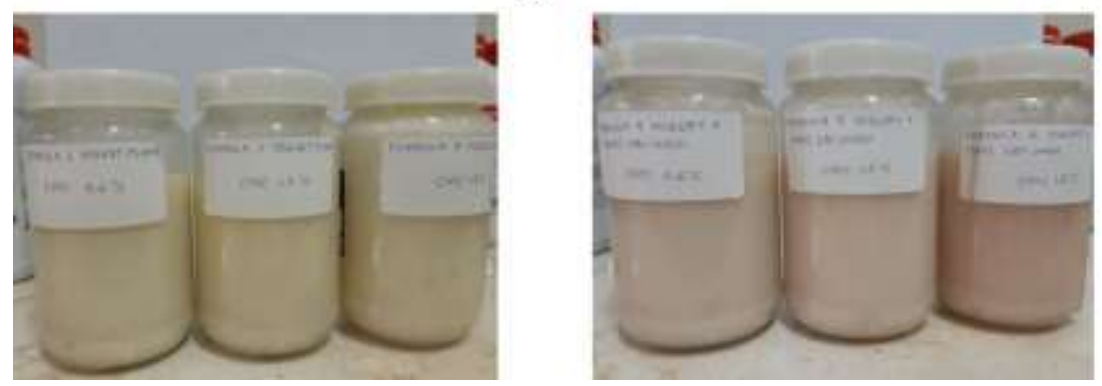

Figure 1. Plain and purple sweet potato fortified yogurt: A. Before incubation (upper half), B. After incubation (lower half) 
Table 2. Organoleptic characteristics and pH of purple sweet potato yogurt before and after incubation

\begin{tabular}{|c|c|c|c|c|c|c|c|c|c|c|c|}
\hline \multirow{3}{*}{ For-mula } & \multicolumn{5}{|c|}{ Before incubation } & \multicolumn{5}{|c|}{ After Incubation } & \multirow[t]{3}{*}{ Notes } \\
\hline & \multirow[b]{2}{*}{$\mathrm{pH}$} & \multicolumn{4}{|c|}{ Organoleptic Characteristics } & \multirow[t]{2}{*}{$\mathrm{pH}$} & \multicolumn{4}{|c|}{ Organoleptic Characteristics } & \\
\hline & & Color & $\begin{array}{l}\text { Tex- } \\
\text { ture }\end{array}$ & Scent & Flavor & & Color & Tex-ture & Scent & Flavor & \\
\hline 1 & $\begin{array}{l}6.08 \pm \\
0.001\end{array}$ & white & $\begin{array}{l}\text { rather } \\
\text { thick }\end{array}$ & milk & sour & $\begin{array}{l}4.15 \pm \\
0.001\end{array}$ & white & liquid & yogurt & Sour & \\
\hline 2 & $\begin{array}{c}6.2 \pm \\
0.002\end{array}$ & white & thick & milk & sour & $\begin{array}{l}4.45 \pm \\
0.002\end{array}$ & white & thick & yogurt & Sour & \\
\hline 3 & $\begin{array}{l}6.19 \pm \\
0.001\end{array}$ & white & $\begin{array}{l}\text { very } \\
\text { thick }\end{array}$ & milk & sour & $\begin{array}{l}4.43 \pm \\
0.002\end{array}$ & white & $\begin{array}{l}\text { very } \\
\text { thick }\end{array}$ & yogurt & Sour & $\begin{array}{l}\text { Foaming } \\
\text { and } \\
\text { agregation }\end{array}$ \\
\hline 4 & $\begin{array}{c}6.1 \pm \\
0.003\end{array}$ & purple & $\begin{array}{l}\text { rather } \\
\text { thick }\end{array}$ & milk & sour & $\begin{array}{l}4.20 \pm \\
0.001\end{array}$ & pink & liquid & yogurt & Sour & \\
\hline 5 & $\begin{array}{l}6.16 \pm \\
0.001\end{array}$ & purple & thick & milk & sour & $\begin{array}{l}4.15 \pm \\
0.003\end{array}$ & pink & thick & yogurt & Sour & \\
\hline 6 & $\begin{array}{l}6.08 \pm \\
0.001\end{array}$ & purple & $\begin{array}{l}\text { very } \\
\text { thick }\end{array}$ & milk & sour & $\begin{array}{l}4.15 \pm \\
0.001\end{array}$ & pink & $\begin{array}{l}\text { very } \\
\text { thick }\end{array}$ & yogurt & Sour & $\begin{array}{l}\text { Foaming } \\
\text { and } \\
\text { agregation }\end{array}$ \\
\hline
\end{tabular}

Further observation was done on formulas 1,2, 4 and 5; including density, viscosity, and stability tests using the centrifugation method. It needed density evaluation to determine the purity and degree of polarity of all yogurt formulas (Ibrahim et al., 2020). The result told us that the product's density in all formulas was lower than water density, $1 \mathrm{~g} / \mathrm{mL}$ (Table 3). This indicated that yogurt had a non-polar characteristic.

The viscosity data explained that yogurt fortified with purple sweet potato has a lower viscosity than plain yogurt. This condition may occur because the purple sweet potato has a watery consistency added to yogurt. However, this result was in line with carboxymethylcellulose sodium's function as a stabilizer whose concentration is in line with yogurt's viscosity. Therefore, the formula with $0.6 \%$ carboxymethylcellulose sodium is less stable than the formula with a $1.2 \%$ (Table 3). These results also prove that sodium carboxymethylcellulose was significantly influenced in stabilizing yogurt by increasing its viscosity.

To determine the gravity effect on the yogurt colloid system stability, we evaluated it using the centrifugation method. Formula 1 and 4 used carboxymethylcellulose sodium concentrations of $0.6 \%$, while formulas 2 and 5 used $1.2 \%$. As a result, formulas 1 and 4 showed more significant phase separation than in formulas 2 and 5. The other formulas showed less phase separation and appeared more stable than the previous. These showed that there were phase separation in all formulas.

The purple sweet potato puree was made with 1:1 ratio for tuber and water. Therefore, the yogurt's texture became very watery and cause phase separation due to decreased water-binding capacity after the addition of puree into the yogurt. This condition also showed that $0.6 \%$ carboxymethylcellulose sodium concentration was not enough to increase water binding capacity and stability (Table 3).

The $\mathrm{pH}$ level also influenced the water-binding capacity. The acidic environment around the isoelectric point caused casein ion decrease, leading to instability of casein micelles and becoming amino acid precipitation (Sawitri et al., 2008; Sinaga et al., 2017). Also, low-fat milk contributed to the formation of phase separation. Other factors that also influence were fat in low-fat milk and the heating process, which caused new casein micelles with lower water-binding capacity (Layadi et al., 2009; Mahomud et al., 2017). 
Table 3. Physical chatareristic of purple sweet potato fortified yogurt

\begin{tabular}{cccc}
\hline Formula & $\boldsymbol{\rho}(\mathbf{g} / \mathbf{m L})$ & Viscosity $(\mathbf{C p s})$ & Phase Separation \\
\hline $\mathbf{1}$ & 0.390 & 475 & $(++)$ \\
$\mathbf{2}$ & 0.391 & 960 & $(+)$ \\
$\mathbf{4}$ & 0.389 & 70 & $(+++)$ \\
$\mathbf{5}$ & 0.391 & 215 & $(++)$ \\
\hline
\end{tabular}

Information:

Phase separation occur: (+) less, (++) intermediate, (+++) abundant

The freeze-thaw test was done in one cycle to investigate the stability. The sample was frozen at $-8^{\circ} \mathrm{C}$, then thawed at room temperature $\left(28^{\circ} \mathrm{C}\right)$. Phase separation tended to happen during the thawing process when the sample was left for 24 hours at room temperature. It indicated that the yogurt sample was not stable if stored in room temperature for 24 hours. This means the optimal temperature for storing yogurt is around $4^{\circ} \mathrm{C}$ to $8^{\circ} \mathrm{C}$, according to SNI 2981.

Table 4. Purple sweet potato fortified yogurt

\begin{tabular}{|c|c|c|c|c|c|c|c|}
\hline \multirow{2}{*}{ Day } & \multirow{2}{*}{$\begin{array}{c}\text { Temperature } \\
\left({ }^{\circ} \mathrm{C}\right)\end{array}$} & \multirow{2}{*}{ Formula } & \multicolumn{4}{|c|}{ Organoleptic } & \multirow{2}{*}{$\begin{array}{c}\text { Phase } \\
\text { Separation }\end{array}$} \\
\hline & & & Color & Texture & Scent & Flavour & \\
\hline \multirow[t]{4}{*}{1} & -8 & 1 & white & thick & yogurt & sour & no \\
\hline & & 2 & white & thick & yogurt & sour & no \\
\hline & & 4 & pink & thick & yogurt & sour & no \\
\hline & & 5 & pink & thick & yogurt & sour & no \\
\hline \multirow[t]{4}{*}{1} & 28 & 1 & white & thick & yogurt & sour & yes \\
\hline & & 2 & white & thick & yogurt & sour & no \\
\hline & & 4 & pink & thick & yogurt & sour & yes \\
\hline & & 5 & pink & thick & yogurt & sour & no \\
\hline \multirow[t]{4}{*}{14} & 28 & 1 & white & liquid & yogurt & sour & yes \\
\hline & & 2 & white & thick & yogurt & sour & yes \\
\hline & & 4 & pink & liquid & yogurt & sour & yes \\
\hline & & 5 & pink & thick & yogurt & sour & yes \\
\hline
\end{tabular}

The process was continued by conducting a rheological test to determine the convenience of pouring yogurt into primary packaging. The rheological test used a Brookfield viscometer, which was previously used for viscosity evaluation. As a result, formulas 1, 2, 4, and 5 were classified as non-newton fluids that cannot withstand shear stress, shear rate, and temperature. The graph in Figure 2 shows that all formulas are categorized as pseudoplastic flow type, indicated by a nonlinear graph and no yield value (curve graph). Viscosity decreases as the rate of division increases. This condition generally occurs in long-chain molecules, including gum, sodium alginate, methylcellulose, and carboxymethylcellulose. Meanwhile, the increased shear stress has led to polymer regularity, decreasing the resistance and increasing the shear rate at the next shear stress (Sinko, 2011).

Natural and synthetic gum, like most pharmaceutical products, show pseudoplastic flow. The pseudoplastic flow is indicated by the polymer in solution, as a general rule. The viscosity of the pseudoplastic substance decreases with increasing shear rate (Sinko, 2011). 

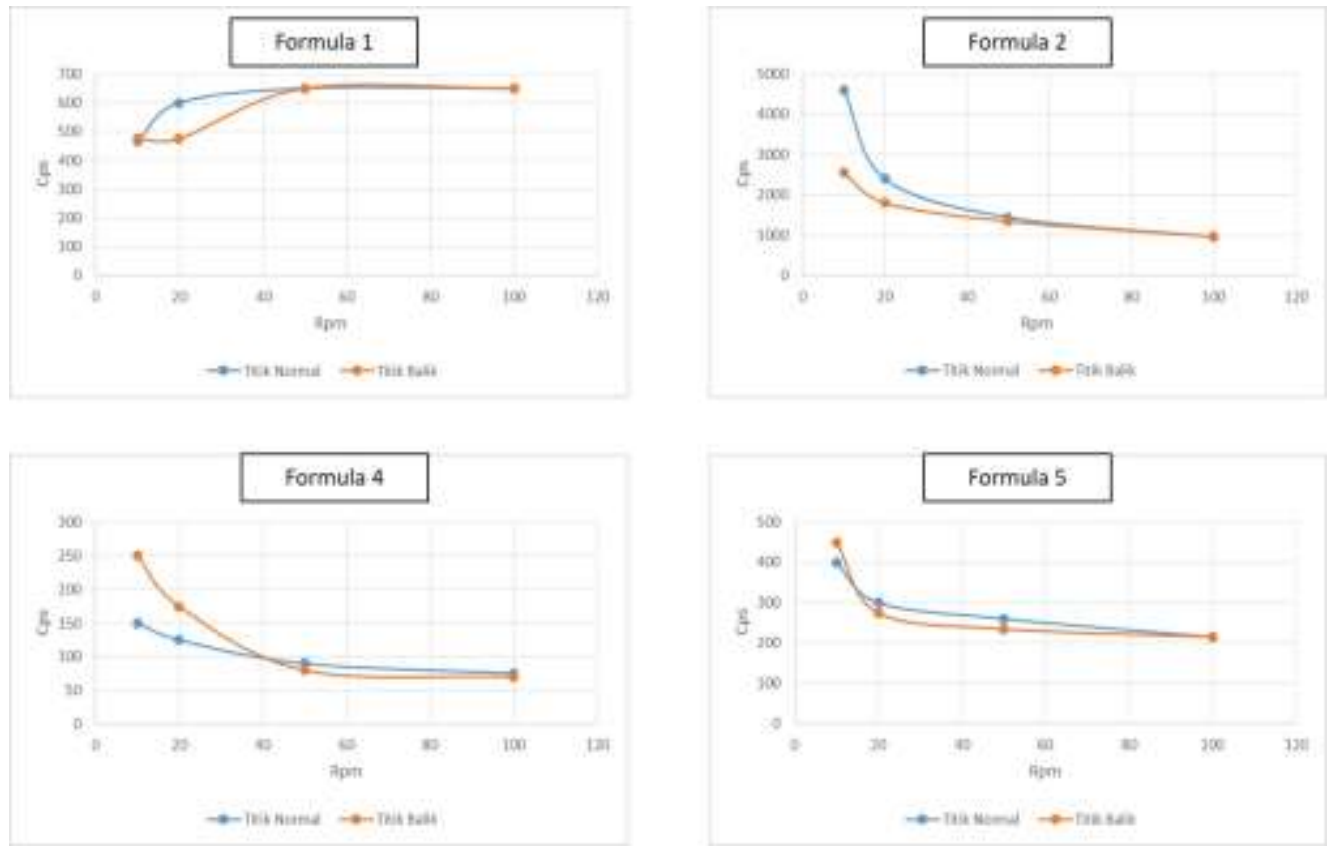

Figure 2. Yogurt Rheologi Graph. Formula 1: (Plain Starter + carboxymethylcellulose sodium 0.6\%), Formula 2: (Plain Starter + carboxymethylcellulose sodium 1.2\%), Formula 4 (Plain starter + Purple sweet potato puree + carboxymethylcellulose sodium $0.6 \%$ ), Formula 5 (Plain starter + Purple sweet potato puree + carboxymethylcellulose sodium $1.2 \%$ )

The graphs showed us that the purple sweet potato yogurt's stability with $1.2 \%$ sodium carboxymethylcellulose as the best. The final product's texture was smoother and thicker, proving that the $1.2 \%$ carboxymethylcellulose sodium concentration can increase the water-binding capacity and product stability.

\section{CONCLUSION}

The yogurt consists of low-fat milk, three bacteria strains, purple sweet potato puree, and three different concentrations of carboxymethylcellulose sodium. Three different concentrations were $0.6 \%, 1.2 \%$ and $1.8 \%$. Formula with $1.2 \%$ carboxymethylcellulose sodium delivered the best result in the physicochemical characteristic of yogurt fortified by purple sweet potato (Ipomoea batatas l.).

\section{ACKNOWLEDGEMENT}

The authors would like to thank all technicians in the Advanced Biomedical Laboratory, Division of Microbiology and Parasitology Laboratory, Faculty of Medicine, Universitas Padjadjaran for all support and technical assistance during this experimental study. This research was supported by Indonesia Endowment Fund for Education (Lembaga Pengelola Dana Pendidikan), Indonesia (grant number: PRJ-51/LPDP/2019).

\section{REFERENCES}

Arancibia, C., Navarro-Lisboa, R., Zúñiga, R. N., \& Matiacevich, S. (2016). Application of CMC as thickener on nanoemulsions based on olive oil: Physical properties and stability. International Journal of Polymer Science, 2016, 1-10. https://doi.org/10.1155/2016/6280581 Bhattarai N, Pradhananga M, M. S. (2015). Effects of various stabilizers on sensorial quality of 
yoghurt. Sunsari Technical College Journal, 2(1), 7-12.

Cakrawati, D., \& Kusumah, M. A. (2016). Pengaruh penambahan cmc sebagai senyawa penstabil $\begin{array}{lllll}\text { terhadap yoghurt tepung gembili. } & \text { Agrointek, }\end{array}$ https://doi.org/10.21107/agrointek.v10i2.2469

Chairunnissa, H., Balia, R. L., Pratama, A., Hadiat, D. R., Teknologi Pengolahan Produk Peternakan, L., Peternakan, F., Bandung Sumedang km, J., \& Sumedang, J. (2017). Karakteristik kimia set yoghurt dengan bahan baku susu tepung dengan penambahan jus bit (Beta Vulgaris L.). In journal.unpad.ac.id (Vol. 17, Issue 1). http://journal.unpad.ac.id/jurnalilmuternak/article/view/14824

He, X., Li, X., Lv, Y., \& He, Q. (2015). Composition and color stability of anthocyanin-based extract for purple sweet potato. Food Science and Technology , 35(3), 468-473. https://doi.org/10.1590/1678-457X.6687

Hornedo-Ortega, R., Álvarez-Fernández, M. A., Cerezo, A. B., Garcia-Garcia, I., Troncoso, A. M., \& Garcia-Parrilla, M. C. (2017). Influence of fermentation process on the anthocyanin composition of wine and vinegar elaborated from strawberry. Journal of Food Science, 82(2), 364-372. https://doi.org/10.1111/1750-3841.13624

Ibrahim, A. I., Rifda, N., Erminawati, W., Hidayah, D., \& Shima, E. H. (2020). Influence of temperature and time on microbial, physicochemical and functional quality of goat milk. African Journal of Food Science, 14(4), 86-91. https://doi.org/10.5897/AJFS2020.1912

Izadi, Z., Nasirpour, A., Garoosi, G. A., \& Tamjidi, F. (2015). Rheological and physical properties of yogurt enriched with phytosterol during storage. Journal of Food Science and Technology, 52(8), 5341-5346. https://doi.org/10.1007/s13197-014-1593-2

Ju, J.-H., Yoon, H.-S., Park, H.-J., Kim, M.-Y., Shin, H.-K., Park, K.-Y., Yang, J.-O., Sohn, M.-S., \& Do, M.-S. (2011). Anti-obesity and antioxidative effects of purple sweet potato extract in 3T3-L1 Adipocytes In Vitro. Journal of Medicinal Food, 14(10), 1097-1106. https://doi.org/10.1089/jmf.2010.1450

Khairani, A. F., Islami, U., Anggun Syamsunarno, M. R., \& Lantika, U. A. (2020). Synbiotic purple sweet potato yogurt ameliorate lipid metabolism in high fat diet mice model. Biomedical and Pharmacology Journal, 13(1). https://doi.org/10.13005/bpj/1874

Layadi, N., Sedyandini, P., Aylianawati, \& Soetaredjo, F. E. . (2009). Pengaruh waktu simpan terhadap kualitas soyghurt dengan penambahan gula dan stabiliser. Widya Teknik, 8(1), 1-11.

Mahomud, M. S., Katsuno, N., \& Nishizu, T. (2017). Role of whey protein-casein complexes on yoghurt texture. Reviews in Agricultural Science, 5(0), 1-12. https://doi.org/10.7831/ras.5.1

Mohan, A., Hadi, J., Gutierrez-Maddox, N., Li, Y., Leung, I. K. H., Gao, Y., Shu, Q., \& Quek, S. Y. (2020). Sensory, microbiological and physicochemical characterisation of functional manuka honey yogurts containing probiotic Lactobacillus reuteri DPC16. Foods, 9(1). https://doi.org/10.3390/foods9010106

Nguyen, L., \& Hwang, E. S. (2016). Quality characteristics and antioxidant activity of yogurt supplemented with aronia (aronia melanocarpa) juice. Preventive Nutrition and Food Science, 21(4), 330-337. https://doi.org/10.3746/pnf.2016.21.4.330

Perna, A., Intaglietta, I., Simonetti, A., \& Gambacorta, E. (2014). Antioxidant activity of yogurt made from milk characterized by different casein haplotypes and fortified with chestnut and sulla honeys. Journal of Dairy Science, 97(11), 6662-6670. https://doi.org/10.3168/jds.2013$\underline{7843}$

Raikos, V., Ni, H., Hayes, H., \& Ranawana, V. (2018). Antioxidant properties of a yogurt beverage enriched with Salal (Gaultheria shallon) Berries and Blackcurrant (Ribes nigrum) pomace during cold storage. Beverages, 5(1), 2. https://doi.org/10.3390/beverages5010002

Sawitri, M. E., Manab, A., \& Palupi, T. W. L. (2008). Kajian penambahan gelatin terhadap keasaman, pH, daya ikat air dan sineresis yogurt. Jurnal Ilmu Dan Teknologi Hasil Ternak, 


$$
3(1), 35-42
$$

Sinaga, H., Bansal, N., \& Bhandari, B. (2017). Effects of milk pH alteration on casein micelle size and gelation properties of milk. International Journal of Food Properties, 20(1), 179-197 https://doi.org/10.1080/10942912.2016.1152480

Sinko, P. J. (2011). Chemical kinetics and stability. In martin's physical pharmacy and pharmaceutical sciences: physical chemical and biopharmaceutical principles in the pharmaceutical sciences: sixth edition. https://doi.org/10.1201/9780203644478.ch8

Sudajana, F. L., Utomo, A. R., \& Kusumawati, N. (2013). Pengaruh penambahan berbagai konsentrasi Na-CMC terhadap sifat fisikokimia dan organoleptik es krim sari biji nangka. Journal of Food Technology and Nutrition, 12(1), 47-54

Teshome, G., Keba, A., Assefa, Z., Agza, B., \& Kassa, F. (2017). Development of fruit flavored yoghurt with mango (Mangifera indica L.) and papaya (Carica papaya L.) fruits juices. ISSN, 67(February 2018), 2224-6088. www.iiste.org

Tokusoglu, O., \& Yildirim, Z. (2012). Effects of cooking methods on the anthocyanin levels and antioxidant activity of a local Turkish sweetpotato [Ipomoea batatas (L.) Lam] cultivar Hatay Kirmizi: Boiling, steaming and frying effects. Turkish Journal of Field Crops, 17(1), 87-90. https://doi.org/10.17557/tjfc.88075

Tsuda, T. (2016). Recent progress in anti-obesity and anti-diabetes effect of berries. Antioxidants, 5(2), 13. https://doi.org/10.3390/antiox5020013

Yang, Z. wei, Tang, C. e., Zhang, J. liang, Zhou, Q., \& Zhang, Z. cheng. (2019). Stability and antioxidant activity of anthocyanins from purple sweet potato (Ipomoea batatas L. cultivar Eshu No. 8) subjected to simulated in vitro gastrointestinal digestion. International Journal of Food Science and Technology, 54(8), 2604-2614. https://doi.org/10.1111/ijfs.14172

Zhao, J. G., Yan, Q. Q., Lu, L. Z., \& Zhang, Y. Q. (2013). In vivo antioxidant, hypoglycemic, and anti-tumor activities of anthocyanin extracts from purple sweet potato. Nutrition Research and Practice, 7(5), 359-365. https://doi.org/10.4162/nrp.2013.7.5.359 
